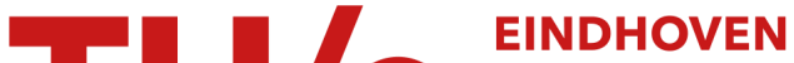 UNIVERSITY OF TECHNOLOGY
}

\section{Ultrasound flow assessment in curved vessels: an in-vitro study}

Citation for published version (APA):

Beulen, B. W. A. M. M., Rutten, M. C. M., \& Vosse, van de, F. N. (2008). Ultrasound flow assessment in curved vessels: an in-vitro study. Poster session presented at Mate Poster Award 2008 : 13th Annual Poster Contest.

Document status and date:

Published: 01/01/2008

\section{Document Version:}

Publisher's PDF, also known as Version of Record (includes final page, issue and volume numbers)

\section{Please check the document version of this publication:}

- A submitted manuscript is the version of the article upon submission and before peer-review. There can be important differences between the submitted version and the official published version of record. People interested in the research are advised to contact the author for the final version of the publication, or visit the $\mathrm{DOI}$ to the publisher's website.

- The final author version and the galley proof are versions of the publication after peer review.

- The final published version features the final layout of the paper including the volume, issue and page numbers.

Link to publication

\section{General rights}

Copyright and moral rights for the publications made accessible in the public portal are retained by the authors and/or other copyright owners and it is a condition of accessing publications that users recognise and abide by the legal requirements associated with these rights.

- Users may download and print one copy of any publication from the public portal for the purpose of private study or research.

- You may not further distribute the material or use it for any profit-making activity or commercial gain

- You may freely distribute the URL identifying the publication in the public portal.

If the publication is distributed under the terms of Article 25fa of the Dutch Copyright Act, indicated by the "Taverne" license above, please follow below link for the End User Agreement:

www.tue.nl/taverne

Take down policy

If you believe that this document breaches copyright please contact us at:

openaccess@tue.nl

providing details and we will investigate your claim. 


\title{
Ultrasound flow assessment in curved vessels: an in-vitro study
}

\author{
Bart Beulen, Marcel Rutten, Frans van de Vosse
}

\section{Introduction}

Ultrasonic perpendicular velocimetry (UPV) (Fig. 1) allows a simultaneous assessment of axial velocity profile and wall position in straight vessels, enabling an accurate flow estimation [1].

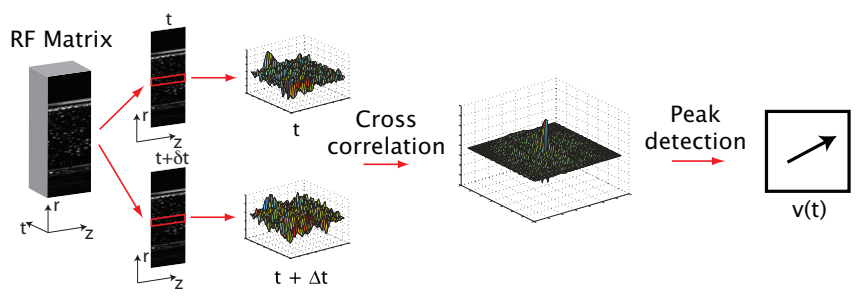

Fig. 1 Schematical overview of UPV.

However, in-vivo, most arteries are curved, causing transversal velocity components, which can have an adverse effect on the performance of UPV. Additionally, the presently applied Poiseuille and Womersley approximations offer a poor estimate for the asymmetrical axial velocity distribution, resulting in inaccurate flow estimations.

\section{Objective}

Validate UPV for instationary non-Newtonian flow in a curved geometry. Estimate the volume flow from the assessed asymmetric velocity profiles and compare the results with the Poiseuille and Womersley approximations.

\section{Methods}

In the experimental setup, a physiologically relevant flow pulse is applied to a curved vessel phantom (Fig. 2). The employed fluid mimics the acoustic and viscoelastic properties of blood.

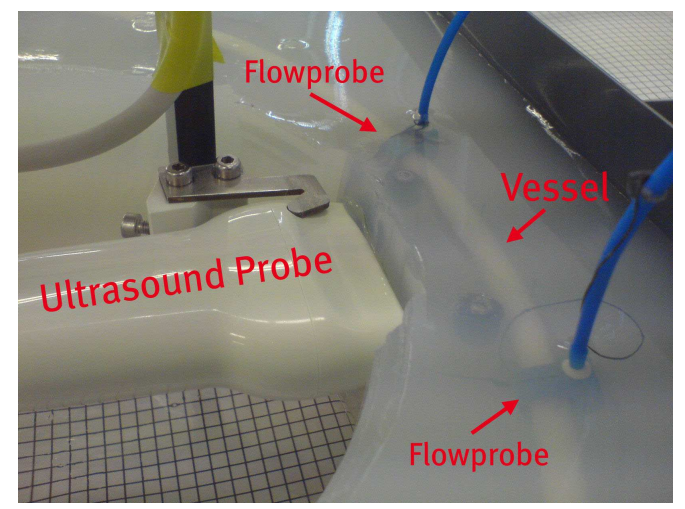

Fig. 2 Ultrasound probe positioned perpendicular to the vessel.

The axial velocity distribution is determined by UPV using a linear array probe and subsequently integrated to yield the flow rate [2]. Simultaneously, the flow rate is measured directly. A finiteelement CFD model of a rigid walled curved vessel is applied to calculate the time-dependent velocity distribution.

\section{Results \\ Velocity profiles}

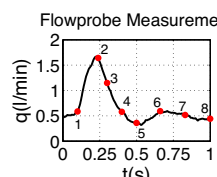

$\mathrm{t}=\mathrm{t}_{3}$
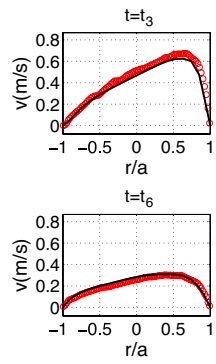

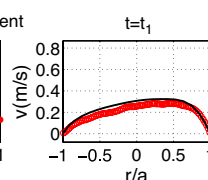

$\mathrm{t}=\mathrm{t}_{4}$

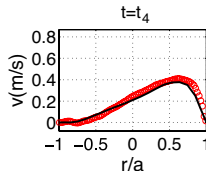

$\mathrm{t}=\mathrm{t}_{7}$

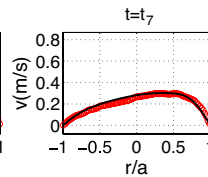

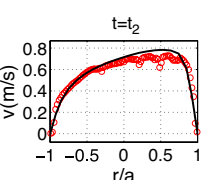

$\mathrm{t}=\mathrm{t}_{5}$

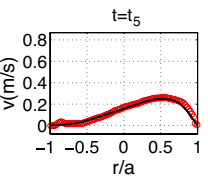

$t=t_{8}$

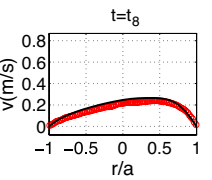

Fig. 3 Comparison of the UPV measurement ( 0 ) and the CFD calculated velocity profiles (-).

\section{Flow rates}

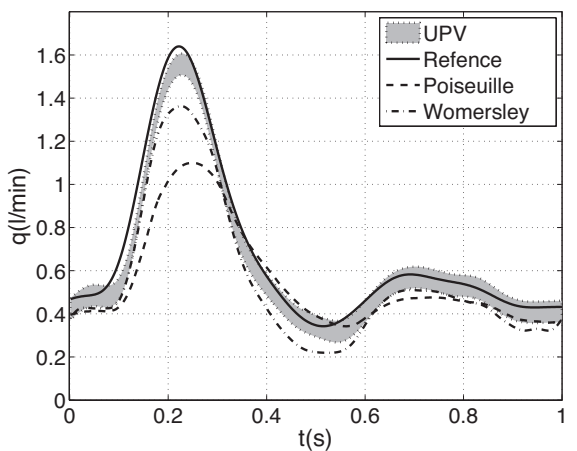

Fig. 4 Comparison of the reference flow measurement and the UPV, Poiseuille and Womersley based flow approximations.

For UPV, the average deviation with respect to the reference flow is about $5 \%$, compared to an average deviation of $20 \%$ for both the Poiseuille and Womersley approximations.

\section{Conclusions}

The UPV method allows an accurate assessment of the axial velocity distribution in a curved vessel. For volume flow estimation it is found that the UPV based flow estimate is far more accurate than the existing Poiseuille and Womersley approximations.

References:

[1] Beulen, B. W. A. M. M. , Rutten, M. C. M. , Brands, P. J. , Vosse, F. N. VAn DE Ultrasound in Med. \& Biol., 2008, submitted

[2] Verkaik, A. C. , Beulen, B. W. A. M. M., Rutten, M. C. M., Vosse F. N. VAn De Phys. Fluids, 2008, submitted 